\title{
ZVLÁDANIE ZÁŤAŽE U PACIENTOV S CIEVNOU MOZGOVOU PRÍHODOU A AKÚTNYM KORONÁRNYM SYNDRÓMOM
}

\author{
Dana Zrubcová, Zuzana Spáčilová, L'uboslava Pavelová, Andrea Solgajová \\ Katedra ošetrovatel'stva, FSVaZ, UKF Nitra \\ dzrubcova@ukf.sk; zspacilova@ukf.sk; lpavelova2@ukf.sk; asolgajova@ukf.sk
}

\begin{abstract}
Abstrakt: Východiská: Adaptívne stratégie zvládania zát’aže sa u pacientov spájajú s dosiahnutím lepších výsledkov v zdravotnom stave pacienta a vyššej kvality života. Ciel: V príspevku analyzujeme, aké stratégie zvládania zát’aže sú zastúpené u pacientov s cievnou mozgovou príhodou a akútnym koronárnym syndrómom. Hodnotíme rozdiely v stratégiách zvládania zát’aže podl'a lekárskej diagnózy, pohlavia a veku pacientov.
\end{abstract}

Metódy: Výberový súbor tvorilo celkovo 79 hospitalizovaných pacientov: 49 pacientov s cievnou mozgovou príhodou $\left(\mathrm{M}_{\mathrm{vek}}=57,22 ; \mathrm{SD}=11,56\right)$ a 30 pacientov s akútnym koronárnym syndrómom $\left(\mathrm{M}_{\mathrm{vek}}=67,03 ; \mathrm{SD}=10,20\right)$. Hodnotenie stratégií zvládania zát'aže prebiehalo 72 hodín po prekonaní ochorenia s použitím dotazníka Brief Cope. Výskum bol schválený etickou komisiou. Išlo o dizajn korelačného deskriptívneho výskumu. Pre štatistické spracovanie dát bol použitý Studentov t-test a Pearsonov korelačný koeficient, prostredníctvom programu IBM Statistics 21.

Výsledky: Zistili sme, že u pacientov s cievnou mozgovou príhodou a akútnym koronárnym syndrómom sú vo vyššej miere zastúpené adaptívne formy zvládania zát’aže. Z maladaptívnych foriem bola v najvyššej miere v obidvoch stavoch zastúpená stratégia Sebarozptýlenie. Podl'a pohlavia boli zistené rozdiely iba v niektorých stratégiách zvládania zát’aže, pričom maladaptívna stratégia Užívanie návykových látok bola viac zastúpená u mužov s cievnou mozgovou príhodou. U mladších pacientov s cievnou mozgovou príhodou bola zastúpená maladaptívna stratégia Sebaobviňovanie viac ako u starších. Adaptívne stratégie u pacientov s akútnym koronárnym syndrómom boli viac zastúpené u mladších pacientov.

Implikácie: V procese starostlivosti je potrebné včas rozpoznat' adaptáciu na ochorenie a spôsoby zvládania a v prípade maladaptívnych stratégií je potrebná aj včasná intervencia za účelom dosiahnutia pozitívnych výsledkov u pacienta v procese liečby.

Kl'účové slová: Zvládanie. Akútne stavy. Vek. Pohlavie. Ošetrovatel'stvo.

\section{Úvod}

Zát’až je podl'a Helusa (2018, s. 173) „namáhanie adaptačných schopností osobnosti organizmu“ a stres ako „zát'až dosahujúca taký stupeň, že hrozí presiahnutie síl jedinca ju zvládat'. To vyvoláva celú radu psychických a fyziologických procesov ohrozujúcich zdravie jedinca, prípadne aj jeho život". Snaha prispôsobit' sa trvalej prítomnosti stresoru môže viest' k vyčerpaniu organizmu, čo má za následok zvýšenú náchylnost' k ochoreniam. Trvalý stres s nízkou intenzitou viac vyčerpáva jedinca ako jednorazový stres vysokej intenzity. Chronický stres môže spôsobit' telesné poruchy ako vysoký krvný tlak, žalúdočné vredy a ochorenia srdca (Helus, 2018). To súvisí nielen s ochoreniami srdca, ale vysoký krvný tlak môže byt' príčinou vzniku cievnej mozgovej príhody.

Vzhl’adom na častý výskyt srdcovocievnych ochorení, najmä cievnej mozgovej príhody a akútneho koronárneho syndrómu odborníci odporúčajú skúmat' aj vplyv modifikovatel'ných 
psychologických faktorov pri vzniku, liečbe a v prevencii srdcovocievnych ochorení. Stratégie zvládania zát’aže môžu byt' vnímané ako modifikovatel'né psychologické charakteristiky, ako tzv. stabilizačné faktory, ktoré môžu jednotlivcom napomáhat’ upevnit' si psychosociálnu adaptáciu počas stresujúceho obdobia a tým predíst' ochoreniu. V prípade, že ochorenie už vznikne Sarason et al. (1990) uvádzajú, že medzi pacientmi, ktorí sa zotavujú zo srdcových ochorení, sa adaptívne stratégie pozitívne spájajú s vyššou kvalitou života a maladaptívne s nižšou kvalitou života. Adaptívne stratégie zvládania zátaže sú spojené s dosiahnutými pozitívnymi zdravotnými výsledkami u pacientov (Chalfont, Bennett, 1999; Svensson et al., 2016), a preto je potrebné podporit' prístupy pre zvládnutie náročnej situácie (Buetow, Goodyear-Smith, Coster, 2001).

Medzi najčastejšie faktory ovplyvňujúce zvládanie zát’aže sa popisuje samotné ochorenie, resp. prejavy a prognóza ochorenia, vek, osobnost', predchádzajúca životná skúsenost' a sociálna podpora (Zacharová, 2017). Ďalej Zacharová (2017) uvádza, že množstvo súčasne prebiehajúcich stresových faktorov zvyšuje náročnost' zátažovej situácia a zvládanie zátaže. Vel'mi podobne popisujú vplyv rôznych faktorov na zvládanie zát’aže u pacientov so srdcovocievnymi ochoreniami aj iní autori, napríklad vplyv pohlavia (Bogg, Thornton, Bundred, 2000), ako aj veku (Buetow, Goodyear-Smith, Coster, 2001).

Vychádzajúc z uvedených teoretických východísk je ciel’om výskumu zistit', ktoré stratégie zvládania zát’aže sú zastúpené u pacientov s cievnou mozgovou príhodou a akútnym koronárnym syndrómom a zistit' rozdiely v stratégiách zvládania zát'aže podl'a typu ochorenia (lekárskej diagnózy), pohlavia a veku pacientov.

\section{Metódy}

Výberový súbor tvorilo $\mathrm{n}=79(100 \%)$ hospitalizovaných pacientov: 49 pacientov s cievnou mozgovou príhodou $\left(\mathrm{M}_{\mathrm{vek}}=57,22 ; \mathrm{SD}=11,56\right)$ a 30 pacientov s akútnym koronárnym syndrómom $\left(M_{v e k}=67,03 ; S D=10,20\right)$. Pacienti boli dotazovaní počas hospitalizácie, 72 hodín po prekonaní cievnej mozgovej príhody alebo akútneho koronárneho syndrómu.

Kzarad'ujúcim kritériám patrili: lekárska diagnóza cievne mozgová príhoda alebo akútny koronárny syndróm, lucídne vedomie, schopnost' komunikácie, schopnost’ spolupráce a vyjadrenie informovaného súhlasu s výskumom.

Pre zber dát bol použitý sebavýpoved’ový dotazník Brief Cope (Carver, 1997), skrátenú verziu dotazníka COPE. Dotazník obsahuje 28 položiek rozdelených do 14 subškál, ktoré predstavujú stratégie zvládania zátaže. K stratégiám zameraným na problém patrí - aktívne zvládanie, plánovanie, inštrumentálna opora, k stratégiám zameraným na emócie patrí emocionálna opora, pozitívne preformulovanie, popieranie, akceptácia, viera a humor. Stratégie zamerané na únik predstavujú ventilovanie, sebarozptýlenie, odangažované správanie, užívanie návykových látok a sebaobviňovanie. Zvládanie zamerané na problém a emócie predstavuje stratégiu adaptívnu a zvládanie zamerané na únik predstavuje stratégiu maladaptívnu. Položky sa hodnotia na štvorstupňovej stupnici: 1 - nikdy, 2 - len výnimočne, 3 - často, 4 - vždy, pričom respondenti vyjadrujú, ako sa v zát'ažových situáciách správali za posledných 6 mesiacov (Baumgartner, 2001, s.198). Pre účely výskumu bola použitá slovenská verzia škály odporučená psychológom, ktorá býva bežne používaná v klinickej praxi.

Zber dát prebiehal v časovom období september 2018 - február 2019. Výskum bol schválený etickou komisiou FN v Nitre, kde výskum prebiehal. Išlo o dizajn korelačného deskriptívneho výskumu. Pre štatistické spracovanie dát bol použitý Studentov t-test dva nezávislé výbery a Pearsonovova korelácia, prostredníctvom štatistického programu IBM SPSS Statistics 21.

\section{Výsledky}


Celkovo vo zvládaní zát'aže boli u pacientov s cievnou mozgovou príhodou a akútnym koronárnym syndrómom preferované vo väčšej miere adaptívne formy zvládania zát’aže.

U pacientov s cievnou mozgovou príhodou patrili medzi najviac preferované a často používané adaptívne stratégie Plánovanie $(M=5,82)$, Inštrumentálna opora $(M=5,67)$, Aktívny coping $(M=5,65)$, Akceptácia $(M=5,65)$, Pozitívne preformátovanie $(M=5,51)$ a Emocionálna opora $(M=5,49)$. Z maladaptívnych stratégií bola ako často používaná stratégia Sebarozptýlenie $(\mathrm{M}=6,06)$.

U pacientov s akútnym koronárnym syndrómom bola z adaptívnych stratégií najviac zastúpená stratégia Akceptácia $M=6,73$, používaná ako často až vždy; ako často využívané adaptívne stratégie boli zastúpené Emocionálna opora $(M=6,30)$ a Inštrumentálna opora $(M=5,80)$. Dalšie adaptívne stratégie boli zastúpené v menšej miere, skôr len výnimočne využívané. Z maladaptívnych stratégií bola používaná stratégia Sebarozptýlenie $(M=5,07)$ v menšej miere ako u pacientov s cievnou mozgovou príhodou (tab.1, graf 1).

Tab. 1 Zvládanie zát’aže u pacientov s cievnou mozgovou príhodou a s akútnym koronárnym syndrómom

\begin{tabular}{|l|c|c|c|c|c|c|}
\hline & \multicolumn{2}{|c|}{ Cievna mozgová príhoda } & \multicolumn{3}{c|}{ Akútny koronárny syndróm } \\
\cline { 2 - 7 } & $\mathbf{N}$ & $\mathbf{M}$ & $\mathbf{S D}$ & $\mathbf{n}$ & $\mathbf{M}$ & SD \\
\hline Sebarozptýlenie & 49 & 6,06 & 1,13 & 30 & 5,07 & 1,53 \\
\hline Aktívne zvládanie & 49 & 5,65 & 1,36 & 30 & 4,30 & 1,06 \\
\hline Popieranie & 49 & 5,10 & 1,45 & 30 & 4,03 & 1,43 \\
\hline Užívanie návykových látok & 49 & 3,84 & 1,85 & 30 & 2,20 & 1,10 \\
\hline Emocionálna opora & 49 & 5,49 & 1,16 & 30 & 6,30 & 1,06 \\
\hline Inštrumentálna opora & 49 & 5,67 & 1,33 & 30 & 5,80 & 1,27 \\
\hline Odangažované správanie & 49 & 4,78 & 1,25 & 30 & 2,67 & 1,03 \\
\hline Ventilovanie & 49 & 5,39 & 1,20 & 30 & 4,17 & 1,46 \\
\hline Pozitívne preformulovanie & 49 & 5,51 & 1,29 & 30 & 3,73 & 1,26 \\
\hline Plánovanie & 49 & 5,82 & 1,15 & 30 & 4,73 & 1,29 \\
\hline Humor & 49 & 4,96 & 1,47 & 30 & 3,30 & 1,69 \\
\hline Akceptácia & 49 & 5,65 & 1,13 & 30 & 6,73 & 1,26 \\
\hline Viera & 49 & 4,63 & 1,90 & 30 & 4,90 & 2,38 \\
\hline Sebaobviňovanie & 49 & 4,88 & 1,22 & 30 & 3,80 & 1,16 \\
\hline
\end{tabular}

Legenda: n - absolútna početnost'; M - aritmetický priemer, SD - smerodajná odchýlka 


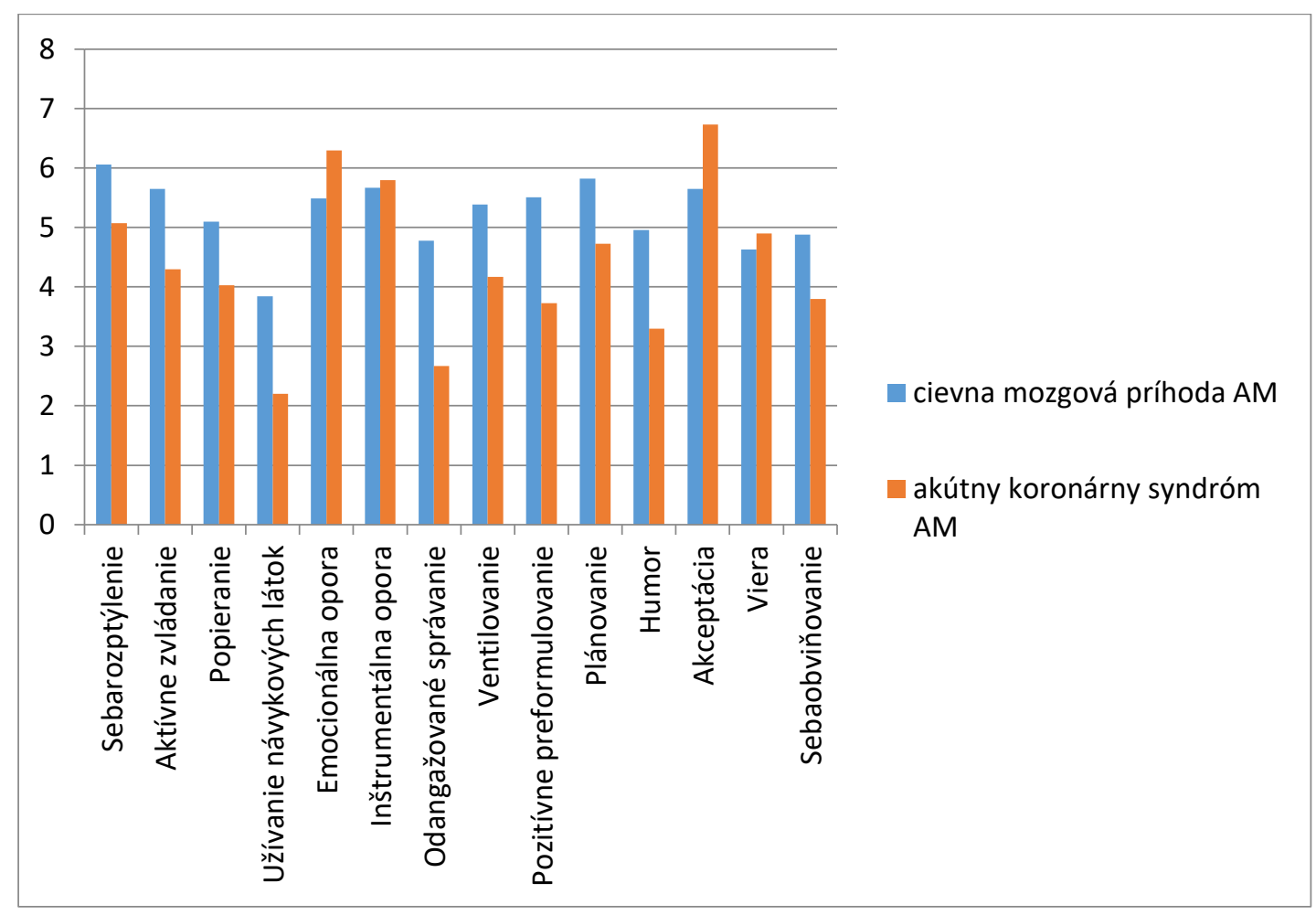

Graf 1 Znázornenie zvládania zát’aže u pacientov s cievnou mozgovou príhodou a s akútnym koronárnym syndrómom

Ďalej boli skúmané rozdiely vo zvládaní zát’aže podl’a pohlavia. U pacientov s cievnou mozgovou príhodou bol zistení štatisticky významný rozdiel v dvoch stratégiách. V maladaptívnej stratégii Užívanie návykových látok ( $\mathrm{p}<0,05)$, ktorá bola zastúpená vo vyššej miere u mužov $(\mathrm{M}=4,41)$. $\mathrm{Z}$ adaptívnych foriem bola u mužov viac zastúpená stratégia Pozitívne preformulovanie $(M=6,09)$ so štatisticky významným rozdielom v porovnaní so ženami $(\mathrm{p}<0,003)$.

U pacientov s akútnym koronárnym syndrómom bol podl’a pohlavia zistený iba jeden štatisticky významný rozdiel, a to v adaptívnej stratégii Viera $(\mathrm{p}=0,001)$, ktorá bola ako často využívaná stratégia u žien $(M=6,38)$, pričom u mužov to bolo iba výnimočne $(M=3,76)$.

Poslednou skúmanou oblast’ou bol aj vplyv veku na vol’bu stratégií zvládania zát'aže u pacientov v akútnom stave. U pacientov s cievnou mozgovou príhodou bol zistený štatisticky významný vzt’ah medzi maladaptívnou stratégiou Sebaobviňovanie a vekom $(r=-0,291)$. V druhej skupine pacientov s akútnym koronárnym syndrómom boli zistené štatisticky významné vzt'ahy medzi adaptívnymi stratégiami a vekom: Aktívny coping $(r=-0,494)$, Plánovanie $(r=-0,560)$, Emocionálna opora $(r=-0,462)$ a stratégiou Humor $(r=-0,366)$.

\section{Diskusia}

Stratégie zvládania zát’aže môžu byt' vnímané ako modifikovatel'né psychologické charakteristiky, ako tzv. stabilizačné faktory, ktoré môžu jednotlivcom napomáhat' upevnit' si psychosociálnu adaptáciu počas stresujúceho obdobia a tým predíst' ochoreniu. V prípade, že ochorenie už vznikne, zvládanie zát’aže je ponímané ako stabilizačný faktor, ktorý jednotlivcom napomáha 
upevnit' si psychosociálnu adaptáciu. Zahŕňa kognitívne a behaviorálne úsilie na zníženie alebo odstránenie stresujúcich podmienok a asociovanej emocionálnej úzkosti (Frasure-Smith, 1991). Pri cievnej mozgovej príhode aj pri akútnom koronárnom syndróme sa popisuje vysoký výskyt emocionálnej úzkosti, a podpora zvládania zátaže má vel'ké opodstatnenie. U pacientov s cievnou mozgovou príhodou sa výskyt úzkosti popisuje u viac ako štvrtiny pacientov (Campbell Burton et al., 2013), u pacientov s akútnym koronárnym syndrómom u viac ako polovice (Frasure-Smith, Lesperance, Talajic, 1993; van Melle, et al., 2004; Sarkar, et al., 2011).

Naše zistenia o zastúpení stratégií zvládania zát'aže v obidvoch skupinách pacientov sú uspokojivé, vzhl'adom na to, že vo väčšej miere sú preferované ako často využívané adaptívne formy zvládania zát’aže, rovnomerne aj na problém aj na emócie zamerané zvládanie zát’aže. Najviac preferovanou stratégiou bola u pacientov s cievnou mozgovou príhodou stratégia Plánovanie (zvládanie zamerané na problém) a u pacientov s akútnym koronárnym syndrómom stratégia Akceptácia (zvládanie zamerané na emócie).

Stratégie zvládania zát’aže predstavujú špecifický spôsob zvládania zát’aže. Výber vhodnej stratégie ul'ahčí prispôsobenie sa novým zmenám a zvládanie zát’ažových situácií bude jednoduchšie (Baštecká a kol., 2015). Podl’a Lazarusa (1996 In Heretik a kol., 2007) reakcia na stresor nie je jednorazová a automatická, ale ide o dynamický proces, v ktorom sa nachádzajú kognitívne a vôl'ové zložky. Kognitívne modely v zvládaní ochorenia pacientom kladú dôraz na myšlienkovú kognitivitu, môže íst' napríklad o model sebaovládanie alebo sebariadenia, tzn. ide o zvládanie ochorenia ako riešenie daného problému, kedy pacient vníma svoje príznaky ochorenia, ale vytvára si svoje vlastné predstavy o ochorení. Riešenie problému znamená dosiahnutie normálneho zdravotného stavu. Zdravotný stav je chápaný ako norma a akékol'vek odchýlky sú chápané ako problémy, ktoré treba akútne riešit’. Motiváciou pre pacienta sú práve tieto odchýlky od normy (Křivohlavý, 2002).

Svensson et al. (2016) uvádzajú, že stratégie zvládania zát’aže zamerané na riešenie problému, sú vo vzt'ahu so zníženým výskytom cievnej mozgovej príhody a úmrtia na srdcovocievne ochorenia. Zároveň uvádza, že stratégia vyhýbanie sa riešeniu problému resp. maladaptívne stratégie boli zistené vo vzt'ahu so zvýšenou úmrtnost'ou u pacientov so srdcovocievnymi ochoreniami, najmä u hypertonikov. Z maladaptívnych stratégií bola ako často používaná stratégia Sebarozptýlenie v obidvoch skupinách pacientov.

Ďalej boli skúmané rozdiely vo zvládaní zát’aže podl'a pohlavia, pričom boli zistené rozdiely $\mathrm{v}$ adaptívnych aj maladaptívnych stratégiách. V skupine pacientov s cievnou mozgovou príhodou bol zistení štatisticky významný rozdiel v dvoch stratégiách. V maladaptívnej stratégii Užívanie návykových látok, ktorá bola zastúpená vo vyššej miere u mužov a zároveň aj v adaptívnej stratégii viac zastúpenej mužov Pozitívne preformulovanie.

U pacientov s akútnym koronárnym syndrómom bol podl'a pohlavia zistený štatisticky významný rozdiel v adaptívnej stratégii Viera, ktorú viac preferovali ženy. Iba zistenia v skupine pacientov s akútnym koronárnym syndrómom sú zhodné so zisteniami autorov Bogg, Thornton, Bundred (2000), ktorí uvádzajú, že ženy po prekonaní akútneho koronárneho syndrómu využívali adaptívne stratégie zvládania zát’aže vo vyššej miere ako muži.

Poslednou skúmanou oblast'ou bol aj vplyv veku na vol'bu stratégií zvládania zát'aže u pacientov v akútnom stave. U mladších pacientov s cievnou mozgovou príhodou bola viac preferovaná maladaptívna stratégia Sebaobviňovanie. V druhej skupine pacientov s akútnym koronárnym syndrómom boli u mladších pacientov viac preferované adaptívne stratégie Aktívny coping, Plánovanie, Emocionálna opora a Humor. Týmto potvrdzujeme, že vek patrí k faktorom ovplyvňujúcim vol'bu stratégií zvládania zát’aže ako uvádza Zacharová (2017). 


\section{Záver}

Zistili sme, že u pacientov s cievnou mozgovou príhodou a akútnym koronárnym syndrómom sú vo vyššej miere zastúpené adaptívne formy zvládania zát'aže. Z maladaptívnych foriem bola v najvyššej miere v obidvoch stavoch zastúpená stratégia Sebarozptýlenie. Podl'a pohlavia boli zistené rozdiely iba v niektorých stratégiách zvládania zát’aže, pričom maladaptívna stratégia Užívanie návykových látok bola viac zastúpená u mužov s cievnou mozgovou príhodou. U mladších pacientov s cievnou mozgovou príhodou bola zastúpená maladaptívna stratégia Sebaobviňovanie viac ako u starších. Adaptívne stratégie u pacientov s akútnym koronárnym syndrómom boli viac zastúpené u mladších pacientov. V celom procese starostlivosti je potrebné včas rozpoznat' adaptáciu na ochorenie a spôsoby zvládania zát’aže. V prípade maladaptívnych stratégií je potrebná včasná intervencia za účelom dosiahnutia pozitívnych výsledkov u pacienta.

\section{Literatúra}

Baštecká, B, Mach, J. a kol. (2015). Klinická psychologie. Praha: Portál.

Baumgartner, F. (2001): Zvládanie stresu - coping. In Výrost, J., Slaměník, I. (Eds.). Aplikovaná sociální psychologie II (s. 191-208). Praha : Grada.

Bogg, J., Thornton, E., Bundred, P. (2000). Gender variability in mood, quality of life and coping following primary myocardial infarction. Coronary Health Care, 4(4), 163-168.

Buetow, S., Goodyear-Smith, F., Coster, G. (2001). Coping strategies in the self-management of chronic heart failure. Family Practice, 18(2), 117-122.

Frasure-Smith, N. (1991). In-hospital symptoms of psychological stress as predictors of long-term outcome after acute myocardial infarction in men. American Journal of Cardiology, 67(2), 121-127.

Helus, Z. (2018): Úvod do psychologie. 2. vyd. Praha: Grada.

Heretik, A., Heretik, A., jr. a kol. 2007. Klinická psychológia. Nové Zámky: Psychoprof.

Chalfont, L., Bennett, P. (1999). Personality and coping: their influence on affect and behaviour following myocardial infarction. Coronary Health Care, 3(3), 110-116.

Křivohlavý, J. (2002). Psychologie nemoci. Praha: Grada.

Sarason, B.R., Sarason, I.G., Pierce, G.R. (1990). Social Support: An Interactional View. New York: John Wiley\&Sons.

Svensson, T. et al. (2016). Coping strategies and risk of cardiovascular disease incidence and mortality: the Japan Public Health Center-based prospective Study. European Heart Journal, 37(11), 890-899.

van Melle J. P., Verbeek D. E. P., van Den Berg M. P., Ormel, J., van Der Linde M. R., De Jonge P. (2006). Beta-blockers and depression after myocardial infarction: a multicenter prospective study. Journal of the American College Cardiology, 48(2), 2209-2214.

Zacharová, E. a kol. (2007). Zdravotnická psychologie: Teorie a praktická cvičení. Praha : Grada Publishing. 
Pomáhajúce profesie, roč. 2, č. 1, 2019, 30-36

\title{
COPING IN PATIENTS WITH CEREBROVASCULAR ACCIDENT AND ACUTE CORONARY SYNDROME
}

\begin{abstract}
Background: Adaptive coping strategies in patients are associated with the achievement of better results in the patients' health status and a higher quality of life. Objective: In the paper, we analyse which coping strategies are present in patients with cerebrovascular accident and acute coronary syndrome. We analyse the differences in coping strategies related to patients' medical diagnosis, gender and age. Methods: The sample consisted of 79 hospitalized patients: 49 patients with cerebrovascular accident $\left(\mathrm{M}_{\mathrm{age}}=57.22 ; \mathrm{SD}=11.56\right)$ and 30 patients with acute coronary syndrome $\left(\mathrm{M}_{\mathrm{age}}=67.03 ; \mathrm{SD}=10.20\right)$. The assessment of coping strategies was conducted 72 hours after the disease outbreak with the use of the Brief Cope inventory. The study was approved by the Ethics Committee. A descriptive correlational research design was used. For statistical data analysis, we used the Student's t-test and the Pearson correlation coefficient in the IBM Statistics 21 programme.

Results: We found out that in the patients with cerebrovascular accident and acute coronary syndrome adaptive forms of coping were present in a higher extent. As for maladaptive strategies, the strategy self-distraction was the most frequent in both conditions. Related to gender, the differences were only found in some coping strategies; the maladaptive strategy substance abuse was more frequent in men with cerebrovascular accident. The maladaptive strategy self-blame was more frequent in younger patients with cerebrovascular accident than the older ones. Adaptive strategies in patients with acute coronary syndrome were more frequent in younger patients.

Implications: In the process of care, early detection of the adaptation to a disease and coping strategies is necessary; in case of maladaptive strategies, an early intervention is also necessary in order to achieve positive results in patients in the treatment process.
\end{abstract}

Keywords: Coping. Acute conditions. Age. Gender. Nursing.

Grantová podpora:

Príspevok bol podporený projektom VEGA 1/0418/19 Zvládanie zátaže v procese rekonvalescencie po cievnej mozgovej príhode. 